\title{
The Problem of Existential Import in Metathetic Propositions: Qutb al-Din al-Tahtani contra Fakhr al-Din al-Razi*
}

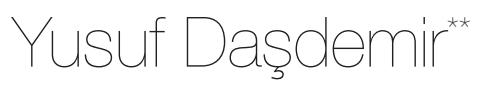

\section{Translated by: Aykut Mustak}

\begin{abstract}
This paper addresses discussions in post-Avicennan Arabic logic on various characterizations of metathetic propositions and their status vis-à-vis the existential import condition by focusing on the arguments made by Fakhr al-Dīn al-Rāzì (d. 606/1210) and the counter-arguments by Quṭb al-Dīn al-Rāzĩ al-Taḥtānī (d. 766/1365), both of whom established their positions in a framework drawn by Avicenna (Ibn Sinā, d. 428/1037), the most prominent figure in the tradition of classical Arabic logic. In his logic texts, Avicenna thoroughly discusses the problem of the existential import in metathetic propositions (ma'dūla), and seems to have presumed the existential import to be a truth-condition for affirmative propositions, and therefore, for affirmative metathetic propositions as well. For Avicenna, in other words, an affirmative metathetic proposition presumes its subject-terms's possibly existent referent(s). However, the theologian-philosopher Fakhr al-Dīn al-Rāzī, who lived about a century and half after Avicenna, criticized his views on metathetic propositions and their existential import among other things, thereby igniting a wave of debates in the tradition, in which Quṭb al-Dīn al-Tahtānī participated in the following century. By studying this contained problem, this paper seeks to address a wider scholarly concern regarding the vitality of post-classical Arabic logic, and to establish that this period witnessed the flourishing of philosophical debate among Arabic logicians.
\end{abstract}

Keywords: Arabic logic, Avicennan logic, existential import, metathetic propositions, Fakhr al-Dīn al-Rāzī, Quṭb al-Dīn al-Rāzì al-Taḥtānī

* This study has received funding from the European Research Council (ERC) under the European Union's Horizon 2020 research and innovation programme (grant agreement No. 682779 - ETI). I would like to thank Kutlu Okan and the anonymous referees of Nazariyat for their suggestions and contributions.

** Postdoctoral researcher, Department of Social Sciences and Philosophy, University of Jyväskylä.

Contact: yusuf.dasdemir@jyu.fi. 


\section{Introduction}

he problem of existential import (hereafter EI), which is closely related to the truth conditions of the propositions may find its expression in the L question: "Is it necessary for a proposition's subject to refer to anything(s) in order for the proposition to be true?"1 Even though the problem has recently come up and been discussed as one of the essential differences between Aristotelian and modern logic, we witness retrospectively that much ink was spilled on the issue in the tradition of Arabic logic as well as in the works of Aristotle (d. 322 BCE) and the Greek commentators. The problem of EI has played a central role, for example, in the discussions of the differences between affirmative metathetic (ma'dūla) and negative simple propositions. Regarding that, Avicenna (d. 428/1037) maintains that just affirmative propositions have EI, a contention that constitutes the most crucial difference between the two propositions. This view, however, would be severely criticized later on by one of his commentators, Fakhr al-Dīn al-Rāzi (d. 606/1210), while some later logicians, a prominent one being Quṭb al-Dīn al-Taḥtānī (d. 766/1365), ${ }^{2}$ attempted to respond al-Rāzī's critique by qualifying Avicenna's theory accordingly. al-Rāzī's objections can be discussed under two titles: (i) "the quality of metathetic propositions" and (ii) "the EI of the negative propositions."

These two issues will be handled in the study's third chapter. Although the main objective here is primarily the treatment of post-Avicennan discussions, the first two sections are devoted to an analysis of Avicenna's position on metathetic propositions and EI, given the centrality of his views to the debates during the following centuries. The first logician to provide a comprehensive treatment of the issues in question herein is the Second Master (al-mu'allim al-thānī) Alfarabi (d. 339/950), who will be referred on the occasions when his position significantly differs from Avicenna's.

This study of post-Avicennan debates in Arabic logic on such an important subject, given its close relationship with the truth conditions of propositions, seeks

1 For a similar formulation of the problem, see John N. Keynes, Studies and Exercises in Formal Logic (New York: Macmillan, 1900), 213.

2 In order to avoid confusion, Quṭb al-Dīn al-Rāzī al-Taḥtānī will be referred to as "al-Taḥtānī" throughout the article. For narrative accounts of his appellation, see Necmi Derin, "Kutbüddin er-Râzînin Hayatı, Eserleri ve Felsefi Görüşleri” (PhD diss., Ankara University, 2008), 5. 
to demonstrate the vivid and dynamic nature of this tradition of logic with various voices and perspectives. Considering the fact that the amount of research on the questions and problems with which this paper deals is quite limited, ${ }^{3}$ it is expected to contribute to the literature on the pertinent areas of research.

\section{Avicenna on Metathetic Propositions}

Aristotle's theory of indefinite names constituted the basis of the discussions on metathetic propositions both in the Greek and Arabic traditions. In De Interpretatione II.16a, 30-31, he talks about nouns with negative prefixes and dubs them "indefinite names" (ónoma aóriston). To him, indefinite names, as exemplified by the term "not-human," are not truly names and no name can stand for the concept on its own. They, though composite, are neither true nor false because their composition differs from that of propositions. ${ }^{4}$ Embracing Aristotle's classification

3 The few studies on the subject, to my knowledge, may be listed in chronological order as follows: Harry A. Wolfson's classical article "Infinite and Privative Judgments in Aristotle, Averroes and Kant," (Philosophy and Phenomenological Research 8, no. 2 [1947]: 173-87) is particularly important for showing the subject's Aristotelian roots and the Greek and Latin parallels of the key terms, in addition to taking up these problems at a very early date. Also remarkable is Paul Thom's treatment of the subject by means of modern logical tools, with particular reference to Alfarabi. See, idem, "Al-Fārābī on Indefinite and Privative Names," Arabic Sciences and Philosophy 18 (2008): 193-209. Necmettin Pehlivan's extensive study, Klasik Mantıkta Ma'dûle Önermelerle Yapılan Çıkarımlar (Ankara: İlâhiyât Yayınları, 2016), also elaborates on the subject. The work's most original contribution, as presented in the introduction, is its discussions of the relationship between metathetic propositions and metaphysical disputes and the role the former played in the latter. The relevant chapters of Ferruh Özpilavcı's study, Fârâbînin Önerme Anlayışı (İstanbul: Litera Yayınları, 2018) also contain significant insights and arguments.

4 Cf. Ibn Sīnā, al-Shifā. al-Manțiq III: al-'Ibāra, ed. Maḥmūd al-Khuḍayrī (Cairo: al-Hay'at al-Mișriyya al'āmma li-l-ta'lif wa-l-nashr, 1970), 12.9-13.6. Although Aristotle did not mention a particular name for the proposition with an indefinite name as its subject or predicate, the Greek commentators, presumably Alexander of Aphrodisias (fl. 200 AD) first, inform us that these propositions were called protasis ek metateseōs or kata metataesin by Aristotle's successor Theophrastus (d. c. 287 BCE) to mean "from transposition" or "by transposition." See Alexander of Aphrodisias, On Aristotle Prior Analytics 1.32-46, trans. Ian Mueller (London: Duckworth, 2006), 93. For various explanations of this designation and the relevant sources in both the Greek text and English translation, see William W. Fortenbaugh, Pamela M. Huby, Robert W. Sharples, and Dimitri Gutas, eds., Theophrastus of Eresus: Sources for His Life, Writings, Thought, and Influence (Leiden: Brill, 1992), 1:148-53. The term was rendered in Arabic as ma'dūla, and it came to be an established term to refer to this kind of propositions. To the best of my knowledge, the oldest extant examples of the term's technical use are present in Alfarabi's commentary on De Interpretatione. Yet, his thoroughly consistent use of "ma'dūl" and "ma'dūla" and their root "udūl" without further justification suggests that the terminology had been largely settled. For Alfarabi’s uses of these terms, see, for example, Abū Nașr al-Fārābī, Sharh alFārābī li-kitāb Arisțūțālīs fĩ al-'Ibāra, ed. Wilhelm Kutsch and Stanley Marrow (Beirut: Dār al-mashriq, 1971), 102 et passim. For a detailed analysis of his views on indefinite notions and privation, see Thom, "Al-Fārābī on Indefinite and Privative Names," 193-209. 
of names as such, Alfarabi and Avicenna define metathetic propositions on that basis. According to Avicenna, "the proposition, then, whose predicate is an indefinite name or an indefinite verb, is called metathetic (ma'dūla/ma'dūliyya) and modified (mutaghayyira)." Although Alfarabi makes use of similar definitions for these terms, ${ }^{6}$ there is a clear disagreement between the two logicians about the meaning of an indefinite name and its semantic content, and thus about the interpretation of metathetic propositions. This disagreement emerges most fully at the point of reading indefinite names to mean non-existence or privation because, as will be elaborated below, Avicenna seems to be opposed to this interpretation.

For him, the simplest form of a proposition is its "binary" (thuna $\bar{a}$ ) form, which consists of a subject and a predicate, in which the copula is latent. When the copula is made explicit, the proposition becomes "ternary" (thulāthī). The word or particle of negation is usually inserted into the ternary proposition in two ways: before the copula or before the predicate. In the first case, the proposition then becomes negative, for the negation attached to the copula does away with the relation between the subject and the predicate, thereby implying the absence of any relation between them. In the second case, the proposition is still positive, but with a negative predicate, that is, metathetic. To continue with Avicenna's examples, of the following two propositions

Zayd is not just.

Zayd is not-just.

the first one is negative whereas the second is metathetic, for the predicate is not "just" but the composite term of "not-just," which goes with the prefix "not(ghayr)" that expresses metathesis ("udūl). Therefore the term "not-just," composed of the word "just" and the prefix "not-," is predicated of the subject, Zayd, in the affirmative way. The metathetic proposition can still be negated by inserting the element of negation into the sentence once more, but this time before the copula in order to disconnect the meaning of "not-just" from the subject: "Zayd is not not-just."

6 al-Fārābī, "Kitāb al-'ibāra," in al-Manțiq 'inda al-Fārābī, ed. Rafīq al-'Ajam (Beirut: Dār al-mashriq, 1985), 1:148; idem, Sharh al-Fārābì, 106.

7 Ibn Sīnā, al-'Ibāra, 77.16-78.10. Also see idem, Kitāb al-Najāt, ed. Majid Fakhrī (Beirut: Dār al-āfāq aljadìda, 1982), 54-55. 
If the copula is implicit, that is to say, if the proposition is binary, then the structure of the Arabic language makes it impossible to ascertain whether the proposition is negative simple or affirmative metathetic. For Avicenna, there is a strong suggestion, especially if the predicate is a verb, that the particle of negation joined to the predicate denies the predication and thereby renders the proposition negative. If the predicate is a noun, on the other hand, then the Arabic word "laysa" is usually used to turn the proposition into negative and "ghayr" into metathetic. ${ }^{8}$

Another kind of proposition closely related to the metathetic is privative propositions (qadāyā 'adamiyya), which Avicenna briefly defines as "the propositions, the predicate of which signifies non-existence of a thing, which is by nature supposed to be existent for the subject or for its species or genus." ${ }^{\prime \prime}$ It is, he says, the prevalent (mashhür) position of that time to define this kind of proposition as "that the predicate of which attests to the lesser of two opposite terms," although the correct definition is the one above. Avicenna, therefore, seems to have distanced himself from his time's prevalent position on the one hand and from such a prominent predecessor of his, namely, Alfarabi, on the other, who sees no harm in holding the popular view having listed the different interpretations of the privative propositions: "Let us take the privative propositions as that which the commentators called 'privative,' namely, the proposition whose predicate is the baser contrary."10

It therefore seems necessary to linger for a while on the privative terms in order to better understand privative statements. While discussing in his al-Maqūlāt VII.1 the different sorts of opposite (mutaqäbil) pairs of terms, which cannot be predicated of the same subject simultaneously and in the same way, Avicenna deals with the relative, contrary, and affirmative-negative terms and then adds to them the concepts of privation and possession. To him, the subject's alternation between a predicate and its opposite, or its variation between two opposite descriptions, is always possible in certain kinds of opposition. Yet others do not allow that; for example, the relation of possession and privation is of the latter kind. After providing the different senses of privation, he explains the primary sense that is taken into consideration in the al-Maqūlāt as follows: 
[M1] Non-existence ('adam) meant herein... is the lack of possession at the [designated] time, i.e., the absence of the potency only through which the action is possible, for the subject will be deprived of potency [in that case] and therefore non-existence cannot be removed any more at all, like blindness. Possession, however, may collapse into privation. Hence, this is the sense of privative opposition mentioned in the al-Maqūlāt. ${ }^{11}$

In this passage, it appears that Avicenna takes privation to mean the removal of potency so as to render the action's reemergence impossible. Thus the potency, once it is turned into privation, will be done away with entirely and it will be impossible for the subject to revert to possession. On the other hand, it will also be impossible to speak of privation in the sense of the potency's disappearance if the subject does not naturally have that potency. Let us say that there is no privation in the case of a wall without sight, to use Avicenna's example, ${ }^{12}$ because it naturally has no faculty of sight and, as such, this cannot be taken as privation. Based on these arguments, it can be suggested that Avicenna adopted the principle Aristotle declared in the Categories (12a30-32): "We speak of privation when an entity that may be endowed with a faculty is entirely deprived of what it has to exhibit by its nature, when it was naturally in its possession." Hence, a proposition with a privative term as its predicate is called a "privative proposition."

As touched upon above in passing, there is a significant disagreement between Alfarabi and Avicenna about the true interpretation of indefinite names and, accordingly, about the relationship between metathetic and privative propositions. While commenting on Aristotle's statement that indefinite verbs can be true of both existent and non-existent subjects (De Interpretatione 16b15-16), Alfarabi

11 Ibn Sīnā, al-Shifā. al-Manțiq II: al-Maqūlāt, ed. Georges Anawati (Cairo: al-Hay'at al-'āmma li-shu'ūn al-mațābi‘ al-amīriyya), 247.3-7. For the different meanings of privation, see Ibn Sīnā, al-Shifā. alIlāhiyyāt, ed. Georges Anawati and Sa'īd Zāyid (Cairo: al-Hay'at al-āmma li-shu'ūn al-mațābi' alamīriyya, 1960), II: 304.17-305.9; cf. Aristotle, Metaphysics V, 1022b22-1023a7. While in al-Ilāhiyyāt Avicenna repeats the different meanings of privation as mentioned by Aristotle's Metaphysics almost verbatim, there is a significant difference between the two texts: Avicenna does not mention Aristotle's examples with the Greek prefix of negation " $\alpha-$-, that will later on be called "alpha negatives." Presumably due to the fact that Arabic's structure does not allow one to draw a distinction between indefinite terms like "not-human," and concepts of alpha negative like "uncountable," "unequal," and so on, this second set is entirely ignored or merged into the indefinite concepts in the works of Arabic philosophers and logicians. Wolfson, however, suggests that the propositions with this kind of concept as their predicates were incorporated into the simple negative propositions. See, Wolfson, "Infinite and Privative Judgments," 184; Stamatios Gerogiorgakis, "Privations, Negations, and the Square: Basic Elements of a Logic of Privations," in Around and Beyond the Square of Opposition, eds. Jean-Yves Béziau and Dale Jacquette (Basel: Birkhäuser, 2012), 230.

Ibn Sīnā, al-Ilāhiyyāt II, 305.1. 
notes that the majority of previous commentators took the statement literally and agreed that the term "not-human" was true of any random thing that was not human, no matter whether it is existent, like "donkey," or non-existent, like "goat-stag." ${ }^{13}$ However, he contends that this interpretation is misleading because indefinite nouns and verbs signify non-existence, and this non-existence is nothing but the privation explained in the Categories as the opposite of possession: "The notion [that the] two indefinites [indefinite noun and verb] signify is the privation that [Aristotle] explained in the Categories. Thus, it is the absence of something from the subject, in which it behooves it to be." ${ }^{14}$ Therefore, there is no difference in Alfarabi's view between the terms "not-sighted" and "blind"; they are identical. However, Avicenna disagrees with him about the identity of the two concepts and criticizes the view that regards metathetic and privative propositions as identical. In his opinion, negation has to do with the proposition's construction ( $t a{ }^{\prime}$ lif $f$ ), and therefore all propositions with the prefix "not-" as their predicates are metathetic. The proposition's matter and quality, however, are different matters. If metathetic propositions were to be interpreted as privative propositions, then the validity of the syllogism given below would be controversial:

[K1] Everything not-subsistent in a subject is a substance.

All bodies are not-subsistent in a subject.

Therefore, all bodies are substances.

According to Avicenna, this syllogism is valid. However, the term "notsubsistent in a subject" does not denote privation because it does not refer to an attribute that is not existent in the substance, but present in its genus, given that substance does not have a genus..$^{15}$ Therefore, it is incorrect to conflate indefinite and privative terms on the one hand and metathetic and privative propositions on the other, for the former is related to the proposition's form whereas the latter is related to its material aspect and content.

In his al-Ishärät wa-l-tanbïhät, Avicenna carries the formalist approach he anticipated above to the next step by omitting the treatment of privative

14 al-Fārābī, Sharh al-Fārābì, 38. Pehlivan grounds the ontological basis of metathetic propositions on the notion of non-existence. Although this approach is sustained in the case of Alfarabi and his followers, it has to be noted that Avicenna, the most outstanding name in the Arabic logic, opposes it. See, Pehlivan, Ma'dûle Önermelerle Yapılan Çıkarımlar, 11-76. 
propositions as a separate category and pointing out that he dismisses the distinction between these two forms of proposition as unnecessary for the logician qua logician, as follows:

[M2] As for the question of whether the metathetic denotes (1) privation, which is contrary to possession, or (2) something else such that not-sighted stands for only the blind or any animal that lost sight even if it [i.e., not-sightedness] is in its nature, (3) or more general a sense, the explanation of this question does not concern the logician, but [rather] the linguist for each and every language. ${ }^{16}$

First, Avicenna draws attention to the three opinions $(1,2,3)$ on the interpretation of metathetic propositions. The first two are based on the interpretation of metathetics as privative propositions, and the last one on the reading of these propositions as two distinct categories:

1. These propositions mean the subject's deprivation of a quality that it naturally ought to have.

2. On a broader reading, these propositions signify the absence of a quality from the subject, whose species or genus is by nature supposed to have that quality.

3. On the broadest reading, they are more general than privative ones; for instance, the predicate of not-sighted may hold of a wall as a subject, although being sighted is not a natural quality of its species or genus.

Yet Avicenna suggests that this discussion is not the logician's task. It would not be wrong to attribute this shift in his position from al-Shifā and al-Najāt to al-Ishārāt to more general one in his approach to logic. He seems to have held the view that logic should be studied as a formal discipline and to have been uneasy with non-formal elements in the logical canon shaped mostly by Aristotle's commentators. He hints this in the introduction of his al-Maqūlāt by pointing out his disapproval of the book being situated within logic ${ }^{17}$ and, finally, entirely excluding the discussion of categories from the logic chapters of his al-Ishärāt. In this context, it is noteworthy that the relation between possession and privation is a problem treated in the book of Categories by both Aristotle and Avicenna. 
Moreover, as stated above, it appears that Avicenna views a proposition's quality as belonging to its formal aspect, but its being privative as belonging to its material aspect. This is why he discussed metathetic statements as a formal issue in his al-Ishārāt, and yet felt free, as a logician, not to discuss their informal aspects. His statements that follow the one quoted above lend support to this interpretation: "All that is required of the logician is to stipulate that if the particle of negation is preceded by, or related to, the copula howsoever, the proposition is affirmative, be it true or false." 18 As is evident, as a logician Avicenna is only concerned with the proposition's formal properties.

To conclude, it seems safe to infer that he regards all propositions with a predicate prefixed by "not-" as metathetic propositions and criticizes all attempts to interpret them as based on non-existence or privation. It is evident that Alfarabi was the most probable target of this criticism, although Avicenna did not mention any name.

\section{Avicenna on The Problem of Existential Import}

It was stated above that the most significant distinction between positive metathetic and negative simple propositions in Avicennan logic ensues from the problem of EI. Now that I have discussed his treatment of metathetic propositions, I would like to move on to examine his stance on the problem of the propositions' EI.

I think the most suitable point to begin the analysis of Avicenna's views about this subject is with his definitions of affirmation and negation in categorical propositions. According to him:

Affirmation $(\bar{i} j \bar{a} b)={ }_{\mathrm{df}}$ the judgment that the predicate exists for the subject.

Negation $(s a l b)={ }_{\mathrm{df}}$ the judgment that the predicate is not existent for the subject. ${ }^{19}$

In a passage where he expounds upon the two definitions and relates them to the problem of EI, he says: 
[M3] All negations hold of non-existents because the affirmation of existent meanings does not hold of them, except for a condition or occasion, which this is not the place to explain, for the affirmation is a judgment about the existence of a meaning for another or the existence of an attribute for an entity, and a meaning cannot exist for something that is not existent. Not to exist, however, is a negation. ${ }^{20}$

It is clear from the passage that Avicenna sees the existence of the subject as irrelevant in negative propositions, which sets the condition of EI exclusively for positive statements. This is because, for him, it cannot be claimed that an attribute of the thing exists unless the thing itself already exists, given that predication is a judgment that something exists for another or for a meaning. ${ }^{21}$ Hence, the subject of an affirmative proposition must above all refer to something that exists in order for the proposition to be true. In line with his theory of mental and external existence, Avicenna interprets this existence in two ways: "Thus, everything subject to affirmation has to exist in particulars or in the mind."22 The existence of the subject, however, is not necessary in the case of negative statements. Given that negation is a judgment to the effect that some meaning or attribute does not exist for a thing, it is also not necessary for the thing to exist in itself. Therefore, a negative judgment may apply to non-existent subjects as well as existing ones. ${ }^{23}$

It has so far been clear, I hope, that the subject of an affirmative proposition has to meet the criterion of $E I$ and that this existence should be realized either in the mental or extra-mental world. The latter of these two modes of being is obvious; however, the former is not because there are some irksome questions about the former, such as what does mental existence truly mean and which entities possess such as existence for Avicenna. To add still more, can we speak of the mental existence of notions which have no referents in the external world at all, or which are impossible even to have such referents? In other words, is it possible to make a positive judgment about them by means of attributing existence to them, even if that existence is mental? Let us try to discuss the possible answers that Avicenna would come up with based on his primary texts.

In order to better understand Avicenna's views about the non-existent things - if we are allowed to call them "things"- we need to assume, I argue, that there are 
two sorts of non-existent ( $m a^{\prime}$ dūm) in his works: (i) the non-existent that does not exist externally but can possibly come into existence howsoever (let us call it the "possible non-existent") and (ii) the non-existent without any possibility of being realized in the external world (let us call it the "impossible non-existent"). ${ }^{24}$ We can exemplify the former case by geometrical objects, such as the heptagonal house (albayt al-musabba) or an icosahedron (dhū 'ishrin qā'ida) ${ }^{25}$ that Avicenna makes use of in various texts. ${ }^{26}$ He speaks of them in the following manner:

[M4] [1] The meaning of affirmation is to judge about the predicate's existence for the subject, and it is impossible to form a judgment about a non-existent thing that something is present in it. Therefore, whatever is subject to affirmation is existent either in particulars or in the mind.

[2] Hence, when one says "The icosahedron is such," by which one means that every icosahedron, however it exists, is such. But it does not mean that every non-existent (ma'düm) icosahedron, while non-existent, is said to be such, for if it is non-existent, then so are its attributes. This is because it is not possible for its attributes to be existent while it itself is not...

[3] On the contrary, the intellect (al-dhihn) makes an affirmative judgment about things, presuming either that the predicates apply to them in themselves and in their [external] existence, or that they are conceptualized in the mind and the predicates hold of them.

[4] However, [the predicates hold of them] not only insofar as they are in the intellect, but also insofar as the predicates exist for them once they exist [externally]. This is so because if the subject has only mental existence at the time of judgment, it will not be possible for us to say of such a thing, B, for example, that it is A, not only in the mind, but also in itself (fi nafs al-amr), since it is not existent in itself. How could it then have an attribute [in itself]? ${ }^{27}$

Although Avicenna did not explicitly make such a classification, I think his references to the second category in some of his texts by expressions like "non-existent in essence impossible of existence" (al-ma'dūm al-dhāt al-mumtani' al-wujūd or al-ma'dūm al-dhāt al-muhāal al-wujūd) lend credibility to such a classification. For such expressions, see Ibn Sīnā, al-Ta lìqāt, ed. Sayyid Husayn Mūsaviyān (Tehran: Mū’assasah-i Pizhūhishī-i Hiikmat va Falsafah-i Īrān, 2013), 527; al-Shifā. al-Manțiq V, al-Burhān, ed. Abū al-'Alā 'Afífī (Cairo: al-Mațba'at al-amīriyya, 1956), 72.4. Nevertheless, the following question comes to one's mind here: "Could the term 'possible' still apply to something that has not existed so far if it will not exist in the future either?" For Avicenna's perspective on this problem, closely related to the principle known as the "principle of plenitude," see Allan Bäck, "Avicenna's Conception of Modalities," Vivarium 30, no. 2 (1992): 217-55, esp. 231-39.

26 One of the most interesting signs of Avicenna's treatment of mathematical objects such as the heptagonal house, in a different manner from imaginary and impossible objects, such as the phoenix, is his substitution of "heptagonal house" for "phoenix" used in ancient sources for universals. For an extensive discussion of the subject and the relevant literature, see Thérèse-Anne Druart, "Avicennan Troubles: The Mysteries of the Heptagonal House and of the Phoenix," Tópicos 42 (2012): 51-73. 
To analyze Avicenna's statements following the order above, we should first concentrate on [1] what he meant by affirmation. His definition of it in [1], I think, suggests two different planes: that of judgment and that of existence. Certainly the plane of judgment is the mind, due to the fact that judging, a mental process, takes place in the mind. In fact, the subject and the predicate are objects that exist in the mind. On the other hand, the plane of existence or, more precisely, the plane of the existence of the attribute to which the predicate refers, for the thing to which the subject refers, is realized either in the external world or in the mind. Therefore, one cannot speak of the existence of any quality for an entity that is not existent in at least one of these two planes. [2] Hence, an affirmative judgment about the icosahedron does not imply that it has a predicate in the duration of its non-existence or insofar as it is non-existent. [3] Such a judgment assumes, first of all, that the icosahedron exists in the external world or in the mind. Yet in the case of things for which it is impossible to exist in the external world, that judgment cannot be made just by assuming its existence in the mind. This is because [4] external existence is fundamental, and the sole way to make an affirmative judgment about something existent only in the mind is to assume its external existence. The icosahedron, like the heptagonal house, lends itself to such a judgment because neither one of them is something impossible to be realized in the external world. In sum, we can truly conclude that this kind of notion possesses an essence and conception, that is to say, a mental existence. ${ }^{28}$ That is why such concepts meet the condition of EI and may be taken as the subject of an affirmative statement, even though currently they have no particular referent outside the mind.

As for Avicenna's impossible non-existents, unlike the previous category of nonexistents, they have neither a quiddity and conception ${ }^{29}$ nor a mental existence. Given the fact that they are fabricated by the human imagination in a way that is contrary to reality, ${ }^{30}$ the impossible non-existents have no quiddity and therefore cannot be defined essentially. These notions exist only in the language as words, and the knowledge of what they mean is obtained by means of nominal definitions. It is not possible, therefore, to predicate something positive of them because they are

Avicenna comes up with the term "heptagonal house" as an example of universals that can be predicated of more than one subject by its very nature, even though it has no particular referents de facto. A universal concept cannot be conceived without a conception or mental existence. See Idem, al-Ilāhiyyāt I, 195.8.

29 "The non-existent has no established essence ('ayn thäbit) that can be pointed at while it is nonexistent." Idem, al-Ta'ìqaàt, 445.

30 For formative process of these notions, see Idem, al-Burhān, 72.3-17. 
in a state of absolute non-existence. Thus the absolute or impossible non-existents do not meet the criterion of EI and cannot be taken as the subject of an affirmative statement, because they have neither an exterior nor a mental existence. The condition on which they can function as the subject of a negative judgment, on the other hand, is explained by Avicenna in al-Ilāhiyyāt I.5, as follows:

[M5] As for the informative statement, it is always about something that is realized (mutahaqqiq) in the mind. An affirmative statement cannot be given about the absolute non-existent. If a negative statement is made about it, then a kind of existence is attributed to it in the mind, for our saying 'it' (huwa) entails a reference and any reference to the non-existent, which has no mental conception at all, is impossible. Then, how can anything be affirmed of the non-existent $?^{31}$

In this passage, Avicenna regards formulating an affirmative proposition about an absolute non-existent as something impossible, whereas he allows negative predications of them only under some conditions. Accordingly, the mind has to attribute a sort of existence to these non-existents in order to render the predication possible, even if it is in negative, for the pronoun "it," which functions as the copula in the proposition, signifies reference and it would be absurd to refer to something that does not have existence even in the mind. In other words, this kind of non-existent may be subject to negative predications after it is given a kind of being in the mind. But does this mean that the impossible non-existents are given mental existence and thus come to meet the condition of EI? If that is the case, then a positive judgment could be made about them and Avicenna's differentiation between affirmative and negative propositions in terms of EI would become irrelevant.

It is clear from the disavowing question at the end of the text that Avicenna does not allow such a conclusion. Thus, we should dwell on how to interpret his statement here that a kind of existence is attributed to the absolute non-existent in the mind. I think that this passage from his al-Ta'līqa t will be helpful in this regard:

[M6] That whose essence is non-existent and whose existence is impossible is not a "thing," and therefore it is impossible to make a positive (wujūdi) , or maybe any, judgment about it. Nonetheless, [if one comes up with the objection that] in this statement ("It is that whose essence is non-existent") that there is a reference to an existent, [then we would say] it is only in terms of utterance. Indeed, there cannot be reference to a non-existent in the real sense. ${ }^{32}$ 
Avicenna first denies the possibility of positive judgment, or even of any judgment, about this kind of impossible non-existent, but then responds to a hypothetical objection that there are, in fact, a positive judgment and a reference to an impossible non-existent in a proposition like "It is that whose essence is nonexistent." For him, the reference here is only verbal because in terms of reality there cannot be a reference to something that is absolutely non-existent. Thus, I do not think that Avicenna attributes mental existence to notions, such as a phoenix, void, God's partner, and so on, which have no possibility of existing in the external world, ${ }^{33}$ but only grants them verbal existence ${ }^{34}$ so that one can speak of them or make a judgment about them, even if only in the negative. ${ }^{35}$ To put it in Fregean terms, such a concept has sense, but no reference in the external world or in the mind..$^{36}$ This sense is given to it by its nominal definition, and the truth value of the propositions about this concept is verified by means of this sense or nominal definition. Since this kind of concept has no reference, the truth value of the judgments about them can be determined only by considering their coherence with the definitions. For instance, the statement that the phoenix is a bird is true if it is consistent with the nominal definition of the phoenix; otherwise, it is false. It has no truth in the sense of correspondence with the external world.

33 To the best of my knowledge, the only text in which Avicenna attributes mental existence to the impossible non-existents, regarding them as intelligible forms, is a letter, the authorship of which is still contested. In it, he deals with the claims that these fictional beings are only existent in the estimation and that they are existent in both the estimation and the mind. He seems to side with the latter: "However, they [the impossible non-existents] are existent in the mind." See Jean Michot, "Avicenna's 'Letter on the Disappearance of the Vain Intelligible Forms after Death'," Bulletin de Philosophie Médiévale 27 (1985): 94-103. To concede, however, that Avicenna holds this position would lead to many inconsistencies on his part in many occasions, among them, for example, what he said about the difference between simple negative and metathetic affirmative propositions. Moreover, there would be no notion about which a positive judgment could not be made. Bearing such problems in mind, I am convinced that it is more reasonable to take Avicenna's authorship of the letter with a grain of salt. Indeed, some specialists of Avicenna's thought, Gutas for example, are of the opinion that the epistle is not authentic. For the arguments, see Dimitri Gutas, Avicenna and the Aristotelian Tradition (Leiden: Brill, 2014), 456.

34 'This is insofar as 'phoenix' is a name that refers to a meaning in the estimation and has no existence at all in the individuals.” Ibn Sīnā, al-'Ibāra, 82.12.

35 "As for the things with no existence whatsoever, the affirmation, which may be possible about them when the mind makes a judgment that 'these are as such,' means that their existence in the mind would as such, if they were existent through a mental existence. It is like saying 'The void has dimensions'." Ibn Sīnā, al-'Ibāra, 80.13-81.1.

36 For Frege's distinction of sense and reference, see Gottlob Frege, "On Sense and Refence," in Translations from the Philosophical Writings of Gottlob Frege, eds. and trans. Peter Geach and Max Black (Oxford: Basil Blackwell, 1960), 56-78. 
This interpretation of Avicenna's relevant texts is also consistent with his theory of science. As explained in al-Burhān I.5, the simple question of "what is it?" which inquires about the nominal definitions of terms, precedes all other questions. Hence, it is not clear yet whether the subject exists at the moment when this question is asked. In this stage, the definiendum of the nominal definition cannot be spoken of, at least without its verbal existence. It is also significant that Avicenna gives the examples of the phoenix and the void when talking about the simple question of "what is it?" in al-Burhān I.5.37

We have mentioned that the most important difference between metathetic affirmative and simple negative propositions surfaces at the point of EI. Avicenna expresses it in the following manner:

[M7] The simple negative is more general than the metathetic affirmative because it can be verily predicated of the non-existent qua non-existent, whereas the metathetic affirmative cannot be verily predicated of that. Thus, while saying "the phoenix is not sighted" is true, "the phoenix is not-sighted" is not. This is insofar as the phoenix is a name referring to a meaning in the estimation and has no existence at all in the individual. ${ }^{38}$

The main factor that determines the difference between a negative proposition like "Zayd is not just" and a metathetic one like "Zayd is not-just" is whether the subject exists or not in the mind or in the external world. If the subject of these two propositions is a concept that meets the condition of $E I$, then they become mutually implicative and identical in a sense.

The disagreement between Alfarabi and Avicenna about the interpretation of metathetic terms appears in this subject again because Alfarabi accepts another difference between simple negative and metathetic affirmative propositions in addition to that related to the condition of EI. According to him, the simple negative proposition is more general than the metathetic one in terms of truth conditions because, given that the metathetic signifies privation, it can only be predicated of those subjects that naturally possess the quality that is the opposite of that privation. In this sense, the predicate "not-acknowledgeable" is synonymous with "ignorant" and can only be predicated affirmatively of a human being who has the capacity to learn, whereas there is no such limitation in the negative proposition. ${ }^{39}$

39 al-Fārābī, "Kitāb al-'ibāra," 148. Also see Thom, "Al-Fārābī on Indefinite and Privative Names," 194-95. 
Avicenna, however, does not agree with that idea and critiques Alfarabi without naming him. Although he concedes it is true that the simple negative proposition is more general than the metathetic affirmative, it would be a mistake to seek a difference between these two forms of propositions regarding their semantic scope, in addition to their dissimilar status in terms of the condition of EI. ${ }^{40}$

After this exposition of how Avicenna conceived the problem, I would now like to proceed to the discussion of Fakhr al-Dīn al-Rāzì's counter-arguments against Avicennan position and Quṭb al-Dīn al-Taḥtānī’s replies.

\section{Quṭb al-Dīn al-Taḥtānī contra Fakhr al-Dīn al-Rāzī}

Fakhr al-Dìn al-Rāzì, the influential theologian-philosopher of the thirteenth century, is one of the two most important commentators of Avicenna's al-Ishārāt. But despite that, he did not refrain from criticizing Avicenna's views on those occasions when he deemed doing so to be necessary and thus stated his own views in this commentary. This makes him the target of Nașir al-Dīn al-Ṭūsî̀s (d. 672/1274) barbed remark that his commentary was a "calumny" (jarh) rather than a "commentary" (sharh). ${ }^{41}$ Historians of Arabic logic, for example Nicholas Rescher, preferred, again based on his critical outlook, to situate al-Rāzī within the Western school that developed in reaction to Avicennism and even noted him as that century's most prominent member of this school. ${ }^{42}$ The main subject of this paper, namely, the problem of EI in metathetic propositions, is also one of the issues on which al-Rāzì adopted a critical stance against Avicenna. Presumably because al-Ṭusî, although he responded to most of al-Rāzī's objections, did not bother to discuss the matter of metathetic propositions, ${ }^{43}$ Quṭb al-Dīn al-Taḥtānī, the most prominent and influential logician of the fourteenth century, took it upon himself to do so. ${ }^{44}$ Particularly outstanding as a logician, al-Tahțānī has become a link in

40 Ibn Sīnā, al-'Ibāra, 81.5-15.

41 Nașīr al-Dīn al-Ṭūsī, "Sharḥ al-Ishārāt wa-l-tanbīhāt," in al-Ishārāt wa-l-tanbīhāt, ed. Sulayman Dunyā (Cairo: Dār al-ma'ārif, n.d.), 1:112.

42 Nicholas Rescher, The Development of Arabic Logic (Pittsburgh: University of Pittsburgh Press, 1964), 66-67.

43 "Since the objections of the great commentator [i.e. al-Rāzī] about this subject do not mar these explanations, but on the contrary are vain oppositions and proofs not based on the established principles and the engagement with them leads to unnecessary lengthiness without bearing any fruit, we ignored them." al-Ṭūsī, "Sharḥ al-Ishārāt," 1:245.

44 In fact, the first response to al-Rāzī's criticisms came from Sayf al-Dīn al-Āmidì. As will be mentioned below, his responses may have exerted some influence on al-Taḥtānī too. See Sayf al-Dīn al-Āmidī, 
the chain of commentators that includes al-Rāzì, al-Āmidī, and al-Ṭūsī, alongside others, with his commentary on Avicenna's al-Ishārāt. ${ }^{45}$

Before going into his criticisms against Avicenna about EI in metathetic propositions, we should take a look at how al-Rāzi interpreted this kind of proposition. In his opinion, there are mainly two approaches to the definition of metathetic propositions, according to the first of which (i) they are the propositions that signify the non-existence of a quality that should be in the subject by its nature; for instance, the indefinite term "not-sighted" is synonymous with "blind" because the faculty of sight is a possession and its non-existence, in the sense of its absence from a subject in which it should naturally be present, is privation, which is the opposite of possession. (ii) The second one takes the metathetic terms in a more general sense. In this reading, these terms signify the non-existence of a quality that is proper for a subject to have due to the nature of its species or genus, even if not by its very nature. For example, when we consider that the lack of sight is a characteristic feature of an animal like the mole's nature, the proposition "The mole is not-sighted" is false according to the first approach, but true according to the second because sight is a property that should be in its genus, namely "animal," by its very nature, even if not its own species. Some of the proponents of the second position, al-Rāzì relates, interpreted metathetic propositions so broadly that these propositions semantically covered the non-existence of the properties the subject should have had due to the nature of both its remote and its proximate genus. ${ }^{46}$

The broadest sense of the metathetic propositions, which Avicenna referred to above by saying "or more a general sense" (see [M2 (3)]) about the definition of them in his al-Ishārāt, seems to have been merged by al-Rāzī into his second approach here. In other words, al-Rāzī contends that Avicenna meant by this expression the position which argues that the proposition is metathetic if it expresses the non-existence of a property in a particular subject that should have it due to the nature of its species or its genus, whether proximate or remote. Therefore, al-Rāzīs two interpretations of metathetic propositions share in the tendency to regard them as privative propositions even if one is more general than the other. Yet as

Kashf al-tamwīhāt fì sharḥ al-Rāzī 'alā al-Ishārāt wa-l-tanbīhāt, ed. Aḥmad Farīd Mazīdī (Beirut: Dār alkutub al-ilmiyya, 2013), 80-81.

45 For an anecdote as to why al-Taḥtānī penned his commentary on al-Ishārāt, see Kātib Çelebī, Kashf alżunūn, ed. M. Şerefeddin Yaltkaya and Kilisli Rifat Bilge (Istanbul: Maarif Matbaası, 1941), 95.

46 Fakhr al-Dīn al-Rāzī, Sharḥ al-Ishārāt wa-l-tanbīhāt, ed. 'Alī Riḍā Najafzādah (Tehran: Anjuman-i Āsāār va Mafākhir-i Farhangī, 1963), 1:155-56. 
I mentioned when discussing [M2] above, I contend that when he said "or more general a sense," Avicenna was referring to the reading of metathetic propositions as being more extensive than privative ones, such that it takes the proposition "The wall is not-sighted" to be true. Indeed, it was also mentioned above that by stressing the formal features of propositions in his al-Ishārāt, Avicenna regards all propositions with an indefinite predicate as metathetic.

al-Rāzì tries to refute both approaches to the definition of metathetic propositions through various arguments. Accordingly, (i) is false because Aristotle employed a syllogism proving that the heavens are neither heavy nor light:

[K2] Everything moving neither from nor towards the center is neither heavy nor light.

The heavens move neither from nor towards the center.

Therefore, the heavens are neither light nor heavy. ${ }^{47}$

For al-Rāzì, the premises of this syllogism are not negative, because if they were both negative then they would yield no conclusion. Yet since they include the negative particles (neither/nor) in their predicates, then they must be metathetic. These predicates ("neither heavy nor light" and "to move neither from nor towards the center"), on the other hand, are alien to the nature of the heavens. Therefore, the first approach to metathetics (i), taking them as propositions that refer to the privation of a quality that should be in the subject by its nature, is false. ${ }^{48}$

He tries also to falsify the second approach (ii) through the following valid syllogism:

[K3] Every not-substance is an accident.

Blackness is not-substance.

Therefore, blackness is an accident.

It is impossible in this syllogism to assume that "substance" may be predicated of blackness due to its species of genus, ${ }^{49}$ presumably because its genus, namely "accident," is opposite to "substance." Therefore, the idea that metathetic propositions signify a property that has to be present in the subject's species or genus is also false. 
As is clear, al-Rāzì criticizes both interpretations of the metathetic but feels no need to advance his own position. This is why he gives the impression of having put forward these arguments as an explication of Avicenna's statements, rather than as an attempt to reflect his own view. In fact, he provides a definition of metathetic propositions parallel to the first approach and Alfarabi's definition in his most important logic work, al-Mulakhkhaș: "The metathetic proposition is a proposition which makes the judgment that the subject does not have a quality that it should have by its very nature at the time." 50 Therefore, it makes more sense to suppose that he adopted the first approach above. Nevertheless, he says also in his al-Ishārāt commentary that:

[M8] We say that it is not necessary for metathesis (udūl) to signify something or some meaning related to privation ('adamī), because when we say "Zayd is not-blind," the proposition is metathetic affirmative, although "not-blind" does not refer a negative meaning (mánā salbì). ${ }^{51}$

Notice that only the formal properties of the proposition are taken into account here, and based on that it is decided whether the proposition is metathetic or not. Thus, granted that this text reflects al-Rāzī's own view, we have to suppose that he entertains contradictory views in his commentary on al-Ishārāt and al-Mulakhkhaș. Bearing in mind that he defines the metathetic proposition as "the proposition wherein the negative particle is part of either the predicate or the subject or both," 52 in his al-Āyāt al-bayyināt one can acquire a better grasp of the difficulty involved in obtaining an exact conclusion about al-Rāzīs understanding of metathetic propositions. He appears to stand at a transitional point in the subject with this ambivalent attitude, for he alternates in different works between the two interpretations that relate, and that do not relate, metathethic propositions to privative ones. The logicians from Avicenna to al-Rāzi defined the metathetic proposition by its formal features, following Avicenna's approach in al-Ishārāt (i.e., the presence of negative particle in its predicate), ${ }^{53}$ whereas the Arabic logicians after al-Rāzì for the most part adopted Alfarabi's conception and regarded these propositions as wholly identical with privative propositions. 
As far as I can tell, the first logician who firmly defends this change or the return from the formalist Avicennan interpretation to the Alfarabian conception is al-Khūnajī (d. 646/1248). In his Kashfal-asrār, he takes a sound and influential step towards the reading of metathetics as privative and the complete exclusion of the privative propositions as an independent category from the literature, stating that "if the predicate of the proposition is existential (wujūdì), then the proposition will be called 'definite' (muhașșala), whether the copula is affirmative or negative. When the predicate is non-existential ('adamī), the proposition is called 'metathetic,' 'modified' (mutaghayyira) and 'indefinite' (ghayr muhașșala)." ${ }^{4}$ Thus, the most important logicians of post-Khūnajī period, such as al-Abharī (d. 663/1265), ${ }^{55}$ alUrmawī (d. 682/1283), ${ }^{56}$ Shams al-Dīn al-Samarqandī (d. 702/1303), ${ }^{57}$ al-'Allāma al-Hillì (d. 726/1325), ${ }^{58}$ 'Alī al-Qūshjī (d. 879/1474), ${ }^{59}$ and Zakariyyā al-Anșārī (d. 926/1520), ${ }^{60}$ defined the metathetic as "the proposition, the predicate of which is non-existential ('adamì)." However, al-Ṭūsī and a few logicians who followed him, such as al-Kātibī (d. 675/1277), ${ }^{61}$ kept holding on to the Avicennan treatment of the propositions. Except for Tajrīd al-'aqā’id, ${ }^{62}$ al-Ṭūsī continued the approach that Avicenna had set in al-Ishārāt and defined the metathetic proposition by the formal structure of its predicate, namely, according to whether it contains a negative particle. ${ }^{63}$ However, as can be understood from al-Hillī's case above, even

54 Afḍal al-Dīn b. Nāmāwar al-Khūnajī, Kashf al-asrār 'an ghawāmị al-afkār, ed. Khaled el-Rouayheb (Tehran: Mū’assasah-i Pizhūhishī-i Ḥikmat va Falsafah-i İrān, 2010), 86.

55 Athīr al-Dīn al-Abharī, Kashf al-ḥaqā’iq fì tahrīr al-daqā’iq, Süleymaniye Library, MS Ayasofya 2453, 19. Nevertheless, in Tanzīl al-afkār al-Abharī employs the formalist definition of the metathetic proposition: "If the predicate of the proposition is attested to by a composite utterance, which consists of a negative particle and another utterance, then the proposition is called 'metathetic'." See Tanzìl alafkār fì ta'dìl al-asrār, Süleymaniye Library, MS Laleli 2562, 10.

56 See Hasan Akkanat, "Kadı Sirâceddin el-Ürmevî ve Metâliu'l-Envâr (Tahkik, Çeviri, İnceleme)” (PhD diss., Ankara University, 2006), 1:31.

57 Şemsüddin es-Semerkandî, Kıstâsu'l-Efkâr: Düşüncenin Kıstası, ed. and trans. Necmettin Pehlivan (İstanbul: Türkiye Yazma Eserler Kurumu Başkanlığı, 2014), 196.

58 al-'Allāma al-Ḥillī, al-Jawhar al-naḍìd fì sharḥ Manțiq al-tajrīd, ed. Muhsin Bīdārfar (Qom: Intishārāt-i Bīdār, 2013), 94.

59 'Alī al-Qūshīi, Sharḥ Tajrīd al-'aqā’id, ed. Muhammad Ḥusayn Zāri'ī Riḍā'ì (Qom: Rā'id, 2014), 545.

60 Zakariyyā al-Anșārī, al-Mațla 'alā matn İsāghūjī (Cairo: Mușțafā al-Bābī al-Ḥalabī wa awlāduhu, n.d.), 41.

61 See Najm al-Dīn al-Kātibī, al-Shamsiyya fĩ qawãìd al-manțiqiyya, ed. Mahdī Faḍlallāh (Beirut: al-Markaz al-thaqāfī al-'arabī, 1998), 213. However, al-Kātibī is also inconsistent in this matter, for he defines the metathetic in his 'Ayn al-qawä'id as "if the one or both of its terms are non-existential, then the proposition is called 'metathetic'." See idem, 'Ayn al-qawāid fí al-manțiq wa-l-hikma, Süleymaniye Library, MS Ragıp Paşa 1481, 38.

62 However, he gives the impression that he explained the metathetic proposition on the basis of privation in Tajrīd al-'aqā’id. Idem, Tajrīd al-'aqā’id, ed. 'Abbās Sulaymān (Cairo: Dār al-ma'ārif al-jāmi'iyya, 1996), 79.

63 See Nașīr al-Dīn al-Ṭūsī, Asās al-iqtibās fì al-manțiq, trans. Mullā Khusraw, eds. Hasan al-Shāfi'ī and Muḥammad al-Sa'īd Jamāl al-Dīn (Cairo: al-Majlis al-a'lā li-l-thaqāfa, 2004), 119; idem, Tajrīd al-manțiq 
the commentators of al-Ṭūsì abandoned this approach. An exceptional name in this regard is al-Taftāzānī (d. 792/1390), who both defines the metathetic by its inclusion of a negative particle and emphasizes that these propositions have nothing to do with the notion of privation at all. ${ }^{64}$

Turning to al-Taḥtānī, it can be noticed that he relates the metathetic proposition to non-existence, thereby following the prevalent positions of the period. In his opinion, if the predicate of a given proposition is related to existence (wujūdi), in the other words if it does not contain any negative element within itself, then it is called "definite" (muhașșala) because what matters here is the occurrence or realization (tahașșul) of the predicate. On the other hand, if the proposition is related to non-existence, then it becomes "metathetic" because the positive and existential meanings are referred to first and immediately, whereas the negative and non-existential meanings are meant only secondarily and by means of existential meanings. Thus, this transition ('udūl) from positive to negative notions is realized by joining the predicate to the particle of negation and merging them together into a new composite predicate. ${ }^{65}$ Though al-Tahtānī adopts a critical stance against al-Khūnajī in general, he curiously repeats the latter's sentences concerning the interpretation of metathetics almost verbatim.

To sum up, during the classical period of Arabic logic there were mainly two readings of indefinite names and therefore of metathetic propositions, one that followed Alfarabi and another one that followed Avicenna. Whereas the first one attempts to explain this kind of proposition based on privation, the second and more formalist one takes into consideration only the negative particle's insertion into the predicate. Whereas the logicians, such as al-Rāzì and al-Ṭusī, take a wavering route between these two perspectives, the logicians who came after alKhūnajī seem to have adopted, for the greater part, an Alfarabian stance. However, given the fact that the period's prominent logicians, like al-Abharī and al-Kātibī, provided different definitions in their various works rather than pursue one of the approaches in a conscious and consistent way, it seems plausible to think that they did not regard these perspectives as mutually exclusive. They may have taken the 
Avicennan definition as belonging the formal aspect of metathetic propositions and the Alfarabian definition as belonging to their material and semantic aspect without seeing therein any contradiction. In any case, what is obvious is that during this period metathetic propositions were generally associated with privation.

Let me pick our discussion up where I left off. Looking at al-Mulakhkhas and Sharh al-Ishārāt, we notice that al-Rāzìss objections and critical arguments against Avicenna's position on metathetic affirmative propositions are primarily concerned with two problems: (i) the quality of metathetic propositions and (ii) the existential import of negative propositions. Let us now move on to discussing the reservations and objections in this order that al-Rāzī sometimes raised without really holding, which accounts for why he was called "the leader of the skeptics" (imam al-mushakkikin). ${ }^{66}$

\subsection{The Quality of the Metathetic Proposition}

Once commenting on the seventh chapter of the third nahj of Avicenna's al-Ishärāt, which is devoted to the subjects of the metathesis ('udūl) and definiteness (tahșill) of propositions, al-Rāzī proceeds to his objections and criticisms by saying "Here is a necessary discussion. ${ }^{67}$ His first objection is about the quality of metathetic propositions or whether they may be affirmative.

[M9] Here one can say: What is reasonably understood from something's being an attribute for another is its presence (thubüt) in it. Its presence in another is, first of all, a derivation of its presence in itself. [That is to say,] whatever is not present in itself cannot be present in another. The predicate of the metathetic proposition, however, is a non-existential entity ( $a m r$ 'adami) because "not-sightedness" is a non-existential nature. It is impossible, therefore, for it to be present in another and thus the metathetic proposition cannot be affirmative. ${ }^{68}$

For the moniker of al-Rāzī, see, for example, Muhammad Bāqir Mīr Dāmād, Kitāb al-qabasāt, ed. Mahdī Muhaqqiq (Tehran: Intishārāt-i Dānishgāh-i Tehrān, 1988), 73.

67 al-Rāzì, Sharh al-Ishārāt, 1:158.

68 Ibid., Sharh al-Ishārāt, 1:158-59. In Manțiq al-mulakhkhaș, he makes the same argument in the following manner: "When we say 'Zayd is not-sighted', the actual predicate is a specific non-existence, that is, the non-existence of sight. Yet, since the reference to a specific non-existence become possible only by first mentioning the affirmation, which is in opposition to it [i.e. the specific non-existence], we certainly mentioned the affirmation so that we could refer to the specific non-existence by means of it, a non-existence that we wanted to predicate it [of the subject, Zayd]. Then, since the actual predicate is a non-existence, we shall say 'Non-existence does not require an already present (thäbit) subject (maḩall)'." See idem, Manțiq al-mulakhkhaș, 137. 
Rāzì may have taken up this objection as a probable and perhaps plausible argument, rather than part of his own thought. Nevertheless, let us assume that he adopted this view and call it al-Rāzî̀s first thesis (RzT-1):

RzT-1: The metathetic proposition cannot be affirmative.

We come across three premises once we analyze al-Rāzịs argument to justify this thesis:

(P1) What is reasonably understood from something's being an attribute for another is its presence in it.

(P2) Its presence in another is a derivation of its presence in itself, because whatever is not present in itself cannot be present in another.

(P3) The predicate of the metathetic proposition, however, is a non-existential entity.

(Conclusion) Therefore, the presence of the metathetic proposition's predicate in its subject, in other words, the metathetic proposition's being affirmative, is impossible.

In (P2), al-Rāzì apparently appeals to a different usage of a principle found in Avicenna that later came to be called the "principle of derivation." ${ }^{69}$ According to this principle, which is a different formulation of the EI condition, something's predication of another depends, first of all, on the condition of the presence of the subject in itself (muthbat lah) because it is not possible to speak of the attributes of anything that does not exist in itself. Here, we see the hypothetical objector reversing, in a sense, the principle by basing the validity of predication on the existence of the predicate, rather than, or alongside, the existence of the subject (let's call it PEI [the predicate's existential import]). However, al-Rāzī finds the condition of PEI inadequate without going into much detail about it, and also concedes that one of

69 The most general form of this principle, which has had various formulations and interpretations, is like: "Something's presence in another is a derivation of the presence of that in which it is present" (Thubütu shay'in li-shay'in far'u thubüti al-muthbati lahü). For the details of the principle that came up particularly in the context of the essence-existence relationship in post-classical Islamic thought and was generally regarded as invalid in simple whether-ness (haliyya basița) questions (like "Is Zayd [existent]?"), in which the predicate is simply existence, see 'Alī Āl Kāshif al-Ghițā, Naqd al-ārä’ almanțiqiyya wa-ḥall mushkilātihā (Beirut: Mū’assasat al-nu'mān, 1991), 2:352-68. al-Rāzī also adopts the above formula of the principle. However, he appeals to the concept of actualization (hușül) instead of presence (thubūt). Idem, al-Mabāhith al-mashriqiyya fì 'ilm al-ilāhiyyāt wa-l-tabī'iyyāt, ed. Muhammad al-Mu'tașim billāh Baghdādī (Beirut: Dār al-kitāb al-'arabī, 1990), 1:130. On the other hand, as far as I can trace, it was Mullā Șadrā who first explicitly called this principle the 'principle of derivation' (al-qā'idat al-far'iyya or, more properly, qã'idat al-far'iyya). See idem, Metaphysical Penetrations/Kitāb al-Mashā'ir: A Parallel English-Arabic Text, trans. Seyyed Hossein Nasr, ed. İbrahim Kalın (Provo, UT: Brigham Young University Press, 2014), 29 et passim. 
the premises (P2) of the argument above is false: "A more thorough investigation (ziyādat al-tahqia) about the subject yields this: The condition of metathetic propositions is not the existence of the predicates [in themselves], but [rather] the existence of the relations of the subjects to them [i.e. the predicates]."70 Since the truth of the conclusion made in the argument above depends on the truth of the premises altogether, the falsity of a single premise invalidates the argument as a whole. Therefore, RzT-1 is refuted by al-Rāzī's own concession.

In fact, a closer examination will show us that both RzT-1 and its second premise (P2) are originally Avicennan. If we first take up how (P2) originates from Avicenna, in his al-Ilāhiyyāt I.5 he appeals to an argumentation to claim that no given subject referring to the non-existent (ma'düm) can accept a predicate. His argument is as follows: The predicate of a subject that refers to the non-existent either (i) exists for this non-existent or (ii) does not exist for it. If the predicate is existent for this subject (i), it is either (ia) existent in itself or (ib) not existent. According to Avicenna, (ia) is not true because we cannot speak of the existence of a predicate or an attribute of a given subject that is non-existent itself. On the other hand, neither can (ib) be true because, in Avicenna's words, "how can anything non-existent in itself exist for another, for all that is not existent in itself is impossible to exist for another." 71 Then inevitably (ii) is true, that is to say: the non-existent cannot be subject to any predicate. However, what most interests us in this argument is Avicenna's justification for the falsehood of (ib): anything not existent in itself cannot exist for another. As is obvious, this is a slightly different version of the PEI condition in (P2) of al-Rāzì's argument above. This suggests that Avicenna, at least here, supports the PEI condition. However, such an approach is laden with problems because it entails that al-Rāzī's objection in [M9] concerning metathetic proposition should be accepted and that even its scope should be expanded in order to cover privative propositions as well. That is to say, given that the concept of blind, for instance, obviously refers to a meaning deprived of any external referent, would it not be possible to predicate this concept on any subject?

I am of the opinion that a possible way out of the dilemma Avicenna seems to face here can be sought in a cautious or charitable reading of al-Ilāhiyyāt I.5. To do so, first of all, the mode of existence in the proposition "all that is not existent in itself is impossible to exist for another" needs to be disambiguated. If what 
is meant here is that something, say an accident, that is not existent externally cannot subsist in a subject in the external world, this is obviously acceptable. Furthermore, if what is meant is that something with no mental existence even (e.g., an oxymoron like a round square) is impossible to be predicated of a subject in the exterior or mental world, then the proposition is still true. ${ }^{72}$ However, if the proposition is taken to mean that something externally non-existent but mentally existent cannot function as the predicate of any subject, then the principle of PEI will cause many problems in Avicenna's system in general, and in the cases of metathetic and privative propositions in particular. In fact, al-Taḥtānī opines a similar view when dealing with al-Rāzìss objection (RzT-1), presenting his counterargument as follows:

[M10] If what is meant by the presence (al-thubüt) [of something] in another is its existence for it, then we disagree that this is the meaning of affirmation. If what is meant here is its being true of it, then we disagree that for something to be true of another is a derivation of its presence in itself, for it is necessary that non-existents are true of existents, just as the existents are true of them [i.e., existents]. ${ }^{73}$

As might be noticed, al-Taḥtāni refuted the first two premises of RzT1 (P1 and P2), or denied them, to put it in the terms of the art of disputation (ādāb almunāzara) ${ }^{74} \mathrm{He}$ did not object to (P3), equally dubious in my opinion, because this position advanced by Alfarabi, as explained above (i.e., that the metathetic proposition expresses privation) had already become the prevalent and generally accepted position on the subject by al-Tahtānī's time. Nonetheless, I surmise that Avicenna might have said that the metathetic proposition did not express nonexistence, or at least expressed a more general sense than non-existence. In Arabic logic, we find an argument along this line in al-Āmidì (d. 631/1233), who interprets a metathetic proposition like "A human is not-sighted" as "That which is human is that which is not-sighted" and maintains that there is no need at all to claim that the notion of "that which is not-sighted" here does express non-existence. ${ }^{75}$ absolute non-existent (i.e. existent neither in the mind nor in the external world) to be asserted of any subject. See 'Alī al-Qūshjī, Sharḥ Tajrìd, 1:228-29, gloss 2.

73 Quṭb al-Dīn al-Rāzị [al-Taḥtānī], "Sharḥ al-Ishārāt wa-l-tanbīhāt," in al-Ishārāt wa-l-tanbīhāt ma'a sharḥ al-Khwāja Nașìr al-Dīn al-Ṭūsì wa-muhākamāt Quṭb al-Dīn al-Rāzī, ed. Karīm Fayḍī (Qom: Intishārāt-i Maṭbū'āt-i Dīnī, 2004) 1:212.

74 Before al-Taḥtānī, al-Āmīdī raised this same criticism. See al-Āmīdī, Kashf al-tamwīhāt, 80-81.

75 Ibid., 81. 
al-Taḥtānī first targets (P1), which explains what is meant by the proposition's being affirmative, and bases his reply to al-Rāzìs counter-argument on the ambiguity of the term "presence" or "to be present." In his opinion, there are two probable meanings for this term, the first of which is the subsistence of something in another. This meaning appears to be parallel to the relation between accident and substance, or more precisely, the subsistence of an accident in a substance. Accordingly, in order to speak of the presence of an accident in a substance, this table's being white, for example, it is necessary first to concede that the accident "whiteness" exists in itself prior to its existence for the table (certainly this is a priority in nature, not time). al-Taḥtānī does not refute this line of argument, which is patently true, but does note that this is not the meaning of a proposition's affirmativeness. In his opinion, the meaning of "presence" is nothing but "to be truly predicated of." Notice here that the plane of the "presence" has been transferred from the external world to the plane of rational cogitation and the mental world, and that the presence has been interpreted as the truth of the relation between two concepts. Therefore, even a predicate with no referent outside the mind, like that of any metathetic proposition, even though it signifies non-existence, can meet the criterion of presence in the sense of true predication. Thus, al-Tahtānī removes the ambiguity from the concept of existence in Avicenna's PEI principle as well as the concept of presence in al-Rāzī's objection, and suggests that what matters most in terms of predication is mental existence and that there is no need for the external existence of the predicate here. ${ }^{76}$ Thus, by interpreting presence as predication, al-Taḥtānī tries to discard the first and second premises of RzT-1 and thereby invalidate the argument as a whole.

In his commentary on Sirāj al-Dīn al-Urmawīs Mațāli al-anwār, he offers a different reply to the same criticism made by al-Rāzī and confronts the PEI principle head on. For him, what matters in an affirmative proposition is the existence of the thing to which the subject-term refers (dhät al-mawdī). In this sense, the existence of the subject's attribute or predicate is not necessary, and therefore the predication

76 Later on, Mullā Șadrā criticized Avicenna's principle of PEI on the grounds that the existence of the predicate for the subject is not like the existence of accidents and forms and does not require the predicates to exist in themselves. This relation, which only means the predicate's adherence (ta'alluquh) to the subject and its connection (irtibäțh) with it, does not necessitate that the predicate be present or be an entity in itself. See 'Abd al-Rasūl 'Ubūdiyyat, al-Niz̄ām al-falsafì li-madrasat al-hikmat almuta'āliya, eds. 'Alī 'Abbās Mūsawī and Khanjar Hamiyya (Beirut: Markaz al-ḥaḍāra li-tanmiyat al-fikr al-islāmī, 2010), 1:160-63, n. 1. 
of a non-existent predicate of an existent subject is always possible. ${ }^{77}$ Here, it has to be noted, he takes "presence" to mean true predication and uses "existence" to mean external existence. Therefore, a predicate that is non-existent or has no external existence, say not-sighted, cannot be predicated of Zayd, who is existent outside the mind, in the sense of "being an accident that attaches to it" because it is not present in the external world. However, the concept of "not-sighted" present in the mind can be predicated of Zayd, who has an external existence and thus becomes the proposition's subject in the mind at the same time. Yet at least the mental existence of the concepts "Zayd" and "not-sighted" is necessary in this reading, too. ${ }^{78}$ However, as will be seen below, al-Rāzì would not deem such an answer satisfactory.

I have explained above that al-Rāzì himself did not consider the probable objection he raised in [M9] as adequate and thought that, on an in-depth analysis, what mattered in an affirmative proposition was the assertion of a predicate for the subject in any way. The basis of his answer can also be found in Avicenna. Departing from some of Aristotle's insights concerning indefinite terms, ${ }^{79}$ Avicenna refers to the debates among Aristotelian commentators as to whether this kind of name differentiates existent and non-existent things from each other by signifying something definite and, therefore, whether they can be predicated of both existents and non-existents. Against such a background, he states his view as follows:

[M11] We did not stipulate the existence of the subject in metathetic affirmative propositions because our statement "not-just" requires it in itself. Rather, [we stipulated that] because the affirmation requires that in order for it to be true, whether "unjust" applies to both the existent and the non-existent alike, or only to the existent. ${ }^{80}$

In this text, Avicenna shows that he was informed of the disputations about whether indefinite names signified existent things or both existent and nonexistent things. ${ }^{81}$ However, he notes that this would not change the fact that the subject of an affirmative proposition has to be existent. Whether the predicate is a concept related to existence (wujūdì) or to non-existence ('adamì), affirmative

77 al-Taḥtānī, Sharh al-Mațāiti, 2:77. For the fact that this view was also defended by al-Urmawī, see Akkanat, "Kadı Sirâceddin el-Ürmevî ve Metâliu'l-Envâr," 1:33.

78 For similar comments made by al-Dawwānī, see 'Alī al-Qūshjī, Sharh Tajrīd, 1:228-29, gloss 2.

79 Aristotle, “De Interpretatione," 16b13-14.

80 Ibn Sīnā, al-'Ibāra, 82.10-13.

81 For these discussions, see al-Fārābī, Sharh al-Fārābī, 38. 
propositions retain the EI condition and their subjects have to refer to existent things. It becomes obvious, therefore, that al-Rāzī in fact agrees with Avicenna on this matter and that RzT-1 does not present his own opinion, but rather one that he advanced as just a probable objection. Nevertheless, he puts forward another probable objection:

[M12] One may raise such an objection: The statement "The ma'dūm (non-existent) is lā mawjūd (non-existent)" is true, and this proposition is affirmative. In this case, either the subject described as non-existent will be existent, such that two contradictory terms will be identical, which is non-sense, or it [i.e., the subject] will not [be existent]. In this case, the subject of the metathetic affirmative proposition will not be existent. Yet, the Shaykh [Avicenna] was of the opinion that it had to be existent. Then this is also nonsense. ${ }^{82}$

al-Rāzī advances this argument, which at first glance has a paradoxical outlook, to argue again for the thesis that a metathetic proposition does not entail the condition of EI. Thus, we shall call it RzT-2:

RzT-2: The metathetic affirmative proposition does not entail the condition of EI.

He advances the following argument in order to justify this:

(Premise) Since the proposition "The ma'dūm (non-existent) is lā mawjūd (non-existent)" is a metathetic affirmative proposition, the proposition's subject is either (a) existent or (b) non-existent.

(Premise) Not (a), because that would mean the existence of the non-existent, which it is absurd.

(Conclusion) Then (b) is the case, that is, the subject of the metathetic affirmative proposition need not be existent.

To my knowledge, al-Taḥtānī did not respond to this argument. However, what needs to be questioned here is, in my opinion, whether the sentence "The ma'düm (non-existent) is lā mawjūd (non-existent)" is a proposition. As stated above, this kind of concept without an external referent just consists of particular names that have only a verbal existence. Nominal definitions can be given for them in this sense, and, as a matter of fact, we are being faced with a nominal definition here: The concept "ma'dūm" is defined by negating the better-known concept "mawjūd." 
Therefore, as this sentence appears not to be a proposition but rather a nominal definition, its truth-value cannot be contested. Moreover, I find this argument problematic in another aspect: the idea in option (a) of saying that "the non-existent is existent" is absurd is not true because the non-existent, as a term or a name, has a mental existence and it is existent in this sense; it is not non-existent in the absolute sense. In this respect, the mental concept of non-existent is existent but has no referent outside the mind. However, while discussing the status of negative propositions in terms of EI below, I will deal with the possible answer al-Rāzì might have provided against such an idea.

Furthermore, the category of "propositions with negative predicates" (sāliba al-mahnmūl), ${ }^{83}$ which was first advanced by al-Khūnajī, may have been conceived of as a solution to the problematic cases like "The ma'dūm is lā mawjūd" or "The phoenix is non-existent." These propositions with negative predicates, although formally identical to metathetic propositions, are differentiated from the latter in two ways: they do not entail the existence of the subject, and the negative element is not part of the predicate. ${ }^{84}$ As arbitrary as this categorization may seem to be at first glance, it is possibly a helpful tool when it comes to discussing metathetic propositions. On the other hand, we are informed of Greek commentators who claim that metathetics do not entail the EI condition. ${ }^{85}$ Therefore, I think, it would not be incorrect to say that al-Khūnajî's propositions with negative predicates are metathetic propositions without EI condition.

\subsection{The Existential Import in Negative Propositions}

A significant point of objection raised by al-Rāzī concerning metathetic propositions is those negative propositions that do not entail the EI condition. It appears that he had already brought this into discussion and answered it with the reply that the predicate's mental existence is sufficient, which al-Tahtānī also puts forward. In his answer, al-Rāzì argues that if negative propositions do not require EI, it is very possible that this can be applied to affirmative propositions as well:

84 Muhammad A'lā b. 'Alī al-Tahānawī, Mawsū'at Kashshāf iṣțilāhāat al-funūn wa-l-'ulūm, ed. 'Alī Farīd Daḥrūj (Beirut: Maktabat Lubnān, 1996), 965-67.

85 See Sorabji, The Philosophy of the Commentators, 3:288-89. 
[M13] If you argue that "To be a predicate and a subject and the predicates of metathetic propositions, though based on non-existence in the exterior, are mental states, and yet the intellect presumes a kind of existence for them such that it can manipulate them by making them subjects and predicates," then we would respond [by saying] that if it is possible for the intellect to presume a kind of presence for these predicates so as to make them predicates, let it presume existence for them so as to make them subjects, such that affirmation of non-existents renders this possible. In that case, their claim that it is false to say "God's partner is not-sighted" would be invalid. ${ }^{86}$

al-Rāzī claims here that the mental existence argumentation, on which, I suppose, al-Taḥtānī's interpretation of presence as true predication depends, blurs the distinction between affirmative and negative propositions as well as the one between predicates and subjects, all of which means that the EI condition is irrelevant to both forms of proposition. According to him, given that what can be a predicate in a proposition can also be a subject in another proposition, in compliance with the rules of conversion, the subject's existence, just like the predicate's, should be insignificant with respect to the truth value of the proposition. This is because the intellect can make them a subject or a predicate by attributing a kind of existence to them. In other words, a non-existent can be picked up as the subject of a metathetic affirmative proposition. ${ }^{87}$

We can infer from this passage al-Rāzì's third thesis, as follows:

RzT-3: If negative propositions do not entail the EI condition, then neither do affirmative ones.

He also presents this claim in al-Mulakhkhas and questions the principle of "All negations are true of the non-existents," which was shown to originate with Avicenna. For al-Rāzī,

(Premise) What is meant by the proposition "Negation is true of the non-existents" is either (a) what is non-existent in both the mind and the external world or (b) only in the external world.

(Premise) Not (a), because it is impossible to have an affirmative or negative judgment about something that exists neither in mind nor in the external world. 
(Conclusion) Therefore (b) is the case, that is, the non-existent in this proposition is what is non-existent in the external world. However, it is possible that the subjects with no external existence could be the subject of not only negative but also of affirmative statements. Therefore, the EI condition is invalid in the affirmative propositions as well as in the negative ones. ${ }^{88}$

In this objection, al-Rāzī seems to base himself on Avicenna again, for, as we saw above [M5], Avicenna suggested that there can be no judgment concerning what is non-existent in an absolute sense, and thus there has to be an attribution of existence to what is non-existent in order to make even a negative judgment. But the main issue here or, in other words, the bone of contention between the two logicians, is the possibility of categorizing that existence as mental existence. I do not think that Avicenna could have regarded that as mental existence and granted mental existence to what is absolutely non-existent, for if he had, the difference between affirmative and negative propositions in terms of EI, which he reiterated on many occasions, would become meaningless. Therefore, the existence that could be attributed to the non-existent here, as explained above, can only be verbal and linguistic. ${ }^{89}$ In fact, there is no difference between affirmative and negative propositions in the matter of verbal existence, because in order for the nonexistent to be a subject, it should have this verbal existence, regardless of whether the proposition is affirmative or negative. However, it is clear that al-Rāzī holds the view that we cannot make a judgment about anything unless it has existence in the mind. ${ }^{90}$ According to him, when making a judgment about that which has no external existence or cannot possibly exist, one first creates a form of it in the mind and then judge that its existence in the external world is impossible. There is no possibility of making a judgment without such a form. Therefore, what matters in terms of making a judgment is mental existence. ${ }^{91}$

89 The following statement of al-Rāzī on verbal/linguistic existence sheds light on how to understand this kind of existence: "As is obvious to every thinking one, this [verbal/linguistic existence] is only metaphorical and there is no existent in the utterances. (...) To the contrary, it is said 'In this utterance is this meaning,' and what is meant by it is that this word is a sign or a reference for that meaning." See İsmail Hanoğlu, "Fahruddîn er-Râzînin 'Kitâbu'l-Mulahhas fi'l-Mantık ve'l-Hikme’ Adlı Eserinin Tahkîki ve Değerlendirmesi” (PhD diss., Ankara University, 2009), 1:216.

90 "If something does not [even] exist in the mind, it is definitely impossible to point at it. What is as such has neither essence nor reality." al-Rāzī, al-Mabāhith al-mashriqiyya, 1:133.

91 Ibid. Nonetheless, bearing in mind the fact that he denies mental existence in his works, such as alMulakhkhaș, it would make better sense of the difficulty to reach a final conviction concerning al-Rāzīs position on the subject. For his critique of mental existence, see Hanoğlu, "Fahruddîn er-Râzî̀nin 'Kitâbu'l-Mulahhas fi'l-Mantık," 1:213 et passim. 
al-Taḥtānī tries to draw a distinction between affirmative and negative propositions in this context. For him, the mistaken part of the above argument is the notion that we cannot make an affirmative or negative judgment about something that is non-existent without it having a mental existence and that, in this sense, there is no distinction between affirmative and negative propositions because the existence that the subject is expected to have in affirmative propositions is the specified (tafșilì) existence. The subject of a negative existence, however, is not expected to have such an existence. ${ }^{92}$

al-Taḥtānī's other objection against RzT-3 can be located in his commentary on al-Shamsiyya, one of the foremost works of Arabic logic. Commenting on Najm alDīn al-Kātibī's statement "[This is] because affirmation is either true of the realized (muhaqqaq) beings, as in the propositions with subjects existent in the external world (khārijiyyat al-mawdī), or true of hypothetical things, as in the propositions with real subjects (haqiqqiyyat al-mawdū')," ${ }^{33}$ al-Taḥtānī remarks that these are answers to a hypothetical question and quotes those of al-Rāzī's sentences that we cited in [M13]. Here, he tries to respond al-Rāzī's objection above by means of the distinction between the external and real propositions that al-Kàtibì drew again with respect to the subject's EI. Thus, while the subject must exist in the external world in the affirmative form of the external propositions, its hypothetical existence suffices in the real affirmative propositions. Yet there is no such necessity for both kinds of propositions in the negative. ${ }^{94}$

Another important distinction concerning the difference between affirmative and negative propositions in terms of the EI condition was made by al-Sayyid alSharīf al-Jurjānī (d. 816/1413), an indirect disciple of al-Taḥtānī. In his gloss on the latter's commentary on al-Shamsiyya, al-Jurjānī distinguishes between "existence-

92 Al-Taḥtānī, "Sharḥ al-Ishārāt wa-l-tanbīhāt," 1:212.

93 The distinction between real and external propositions, even though it relies heavily on classifications made earlier by Avicenna, was first stated explicitly by al-Rāzì. According to this distinction, if the proposition "A is B" is regarded as a real proposition, then it means "If anything that is qualified as being A were to be existent in the external world, then it would also be qualified as being B." However, if the same proposition is regarded as an external proposition, it is read by considering each individual A as present in the external world. Accordingly, the proposition "Every triangle is a shape" is true as a real proposition because the triangle would be a shape if it were present in the external world. However, it is false as an external proposition because there is currently no triangle in the external world. See alRāzī, Manțiq al-mulakhkhaș, 141-43. For al-Taḥtānī's criticisms and reservations about this distinction, see idem, Sharḥ al-Mațāli', 2:48-57.

94 Idem, Tahrīr al-qawāìd al-manțiqiyya fī sharh al-Risālat al-shamsiyya, ed. Muhsin Bīdārfar (Qom: Intishārāt-i Bīdār, 2005), 270-71. 
cum-presence" and "existence-cum-judgment" and explains this distinction in the following manner:

[M14] Affirmation, insofar it is a judgment, requires the existence of the subject in the mind. It needs the subject (mahkuum 'alayh) to be conceptualized [in the mind] and requires its existence as well. [This is] because the presence of the predicate in the subject is a derivation of its [i.e. the subject's] presence in itself. The difference between these two [modes of] existence is that the existence which the judgment requires is considered only during the judgment, that is, as long as the judge keeps making a judgment with the predicate of the subject, even if it is only for an instant, and that the existence, the presence of the predicate that the subject requires, is according to its presence for it. That is, if it is permanent, so is it; if it is for a moment, so is it; if it is externally, so is it; and if it is mentally, so is it. The negative [proposition] is in common with the affirmative in requiring the first existence, but not the second [existence]. ${ }^{95}$

According to al-Jurjānī, the affirmative proposition (i.e., the affirmation of the subject's predicate), unlike the negative one, necessitates the subject's existencecum-presence. But both affirmation and negation, insofar as they are judgments, necessitate the subject's existence in the mind or, as in al-Jurjānī's classification, existence-cum-judgment. In fact, this distinction between existence-cum-presence and existence-cum-judgment appears to be in close parallel with, or a somewhat different expression of, the distinction made by al-Tahtānī above [M10] as the "existence for the subject" and the "true predication of the subject." The predication of the subject in Tahțānī's classification and the existence-cum-judgment in alJurjānī's are applicable to both existent and non-existent subjects, because the mind attributes a kind of existence to them only for the duration of the judgment. Therefore, both logicians appear to reach an implicit agreement with al-Rāzì by accepting, even if only implicitly, the necessity of mental existence also for the negative proposition's subject.

\section{Conclusion}

At the very beginning, Alfarabi took an important step about the metathetic propositions that Muslim logicians had inherited from Aristotle and his commentators and associated the predicate of these propositions with privation. Therefore, it was agreed that metathetic propositions could only 
apply to those subjects expected to possess the quality that was opposite to the privation in question. Although Avicenna openly criticized this understanding of metathetics, Arabic logic seems to have been shaped, for the most part, by Alfarabi's interpretation. Although al-Rāzì seems to hold apparently inconsistent perspectives on the subject in his various works, al-Tahtānī appears to assume the identity of metathetic-privative propositions.

The problem of EI is significant, particularly with respect to its close relation to the truth conditions of propositions. Avicenna's solution to the problem, which is mostly consistent with that of his predecessors, can briefly described as follows: he takes account of the EI condition exclusively in the affirmative propositions, whether they are particular or universal, including metathetic ones. This EI condition is met by the existence of the proposition's subject either in the external world or in the mind. However, there are occasions on which his views are not quite clear, for instance, on how to assess the status of the propositions with subjects that refer to non-existents. I think he bisects this kind of subjectterms: possible and impossible non-existents. The first of them (e.g., the term "heptagonal house") has a mental existence because its existence in the external world is not impossible. By the same token, it thus meets the condition of EI and therefore can be taken as the subject of an affirmative statement. Yet this does not apply to impossible non-existents. In my opinion, Avicenna is of the view that a term referring to an impossible non-existent has neither an essence and quiddity, nor a genus and differentia, and therefore, no existence at all, not even mental, because the constitutive elements of mental existence are genus and differentia. However, given the fact that we utter positive as well as negative statements about this kind of term, should it have a reality? I surmise that Avicenna would answer this question positively, because he attributes verbal/linguistic existence to this sort of subject. That is to say they do have names, but the objects to which these names refer are existent neither in the external world nor in the mind. While some of Avicenna's statements give the impression that this kind of notion also has a mental existence, the acceptance of such a view would lead to many inconsistencies within Avicennan logic.

Fakhr al-Dīn al-Rāzì criticizes Avicenna at two points: the quality of the metathetic propositions and the EI condition in negative propositions. However, it is not very clear if he agrees with the arguments he advanced. In fact, it is obvious that he does not agree with the first one. For example, he suggests that 
metathetic propositions, whose predicates are indefinite concepts, need not meet the EI condition, since indefinite concepts express non-existence, rather than being related to something positive. This criticism, with which he actually notes his disagreement, was picked up by Avicenna beforehand and replied to. For Avicenna, the subject of an affirmative statement has to refer to something existent, whether its predicate refers something related to existence or non-existence. This is independent of the nature of the predicate, its being an indefinite name, having this or that property. al-Taḥtānī replies to the same criticism by making a distinction between "existence for the subject" and "true predication of the subject." In his opinion, in contrast to being in a subject, the predicate's being true of the subject is not conditional upon the predicate's existence in itself. The notions with no external existence and expressing non-existence in this sense can be predicated of the subject in affirmative propositions.

Avicenna holds that the EI condition will not be sought in negative propositions, for he contends that the judgment in these is that the predicate does not exist for the subject and that such a judgment can be considered for a subject with no existence as well as for a subject with existence. However, there should be no difference between affirmative and negative propositions in this respect, according to al-Rāzì, because neither an affirmative nor a negative judgment can be made if the proposition's subject is in the state of absolute non-existence. If the subject proves to be non-existent, in the sense of being non-existent outside the mind but not in the absolute sense, then an affirmative as well as a negative judgment can be made about this subject. Therefore, he argues that there is no difference between affirmative and negative propositions with respect to the EI condition and that negative propositions, like affirmative ones, cannot be set about an absolutely non-existent subject. In contrast, al-Taḥtānī tries to prove that there is a difference between these two forms of propositions concerning the EI condition. If the affirmative proposition is external, then its subject has to be existent externally; if it is real, then the subject has to be existent, at least hypothetically, in the external world. However, this condition does not apply to negative propositions. al-Jurjānī, on the other hand, tries to respond to the same criticism by making a distinction between the existence-cum-judgment and existence-cum-presence, according to which both affirmative and negative propositions, given that they are both judgments, require the subject's existence-cum-judgment; however, the existencecum-presence only applies to affirmative propositions. 


\section{References}

al-Abharī, Athīr al-Dīn. Kashf al-ḥaquảiq fĩ taḥrīr al-daqā’iq. Süleymaniye Library, MS Ayasofya 2453.

Akkanat, Hasan. "Kadı Sirâceddin el-Ürmevî ve Metâliu'l-Envâr (Tahkik, Çeviri, İnceleme)." PhD diss., Ankara University, 2006.

Alexander of Aphrodisias. On Aristotle Prior Analytics 1.32-46. Translated by Ian Mueller. London: Duckworth, 2006.

al-Āmidī, Sayf al-Dīn. Kashf al-tamwīhāt fì sharh al-Rāzì 'alā al-Ishārāt wa-l-tanbīhāt. Edited by Aḥmad Farīd Mazīdī. Beirut: Dār al-kutub al-'ilmiyya, 2013.

al-Anșārī, Zakariyyā. al-Mațla 'alā matn İsāghūjī. Cairo: Muṣṭafā al-Bābī al-Ḥalabī wa awlāduhu, n.d.

Aristotle. "Categories." In The Complete Works of Aristotle, edited by Jonathan Barnes, 1:3-24. Princeton: Princeton University Press, 1995.

"De Interpretatione." In The Complete Works of Aristotle, edited by Jonathan Barnes, 1:25-38. Princeton: Princeton University Press, 1995.

"Metaphysics." In The Complete Works of Aristotle, edited by Jonathan Barnes, 2:1552-1728. Princeton: Princeton University Press, 1995.

Bäck, Allan. “Avicenna’s Conception of Modalities.” Vivarium 30, no. 2 (1992): 217-55.

Derin, Necmi. "Kutbüddin er-Râzînnin Hayatı, Eserleri ve Felsefi Görüşleri." PhD diss., Ankara University, 2008.

Druart, Thérèse-Anne. "Avicennan Troubles: The Mysteries of the Heptagonal House and of the Phoenix," Tópicos 42 (2012): 51-73.

al-Fārābī, Abū Nașr. "Kitāb al-'ibāra.” In al-Manțiq 'inda al-Fārābī, Edited by Rafīq al-'Ajam, 1:133-64. Beirut: Dār al-mashriq, 1985.

Sharḥ al-Fārābì li-kitāb Arisțūțālīs fi al-'Ibārah. Edited by Wilhelm Kutsch and Stanley Marrow. Beirut: Dār al-mashriq, 1971.

Fortenbaugh, William W., Pamela M. Huby, Robert W. Sharples, and Dimitri Gutas, eds. Theophrastus of Eresus: Sources for His Life, Writings, Thought, and Influence. Leiden: Brill, 1992.

Frege, Gottlob. “On Sense and Refence." In Translations from the Philosophical Writings of Gottlob Frege, edited and translated by Peter Geach and Max Black, 56-78. Oxford: Basil Blackwell, 1960.

Gerogiorgakis, Stamatios. "Privations, Negations, and the Square: Basic Elements of a Logic of Privations." In Around and Beyond the Square of Opposition, Edited by Jean-Yves Béziau and Dale Jacquette, 229-39. Basel: Birkhäuser, 2012.

Gutas, Dimitri. Avicenna and the Aristotelian Tradition. Leiden: Brill, 2014.

Hanoğlu, İsmail. “Fahruddîn er-Râzî̀nin 'Kitâbu'l-Mulahhas fi'l-Mantık ve’l-Hikme’ Adlı Eserinin Tahkîki ve Değerlendirmesi.” PhD diss., Ankara University, 2009.

al-Ḥillī, al-'Allāmah. al-Jawhar al-naḍid fi sharḥ Manțiq al-tajrīd. Edited by Muḥsin Bīdārfar. Qom: Intishārāt-i Bīdār, 2013.

Ibn al-Marzubān, Bahmanyār. al-Taḥṣil. Edited by Murtaḍā Muṭahharī. Tehran: Intishārāt-i Dānishgāh-i Tehrān, 1996.

Ibn Sīnā. al-Ishārāt wa-l-tanbīhāt. Edited by Sulaymān Dunyā. Cairo: Dār al-ma'ārif, n.d. Kitāb al-najāt. Edited by Majid Fakhrī. Beirut: Dār al-āfāq al-jadīda, 1982. 
, al-Shifā. al-Ilāhiyyāt II. Edited by Georges Anawati and Sa'īd Zāyid. Cairo: al-Hay'at al-'āmma lishu'ūn al-mațābi‘ al-amīriyya, 1960.

, al-Shifā. al-Manțiq II: al-Maqūlāt. Edited by Georges Anawati. Cairo: al-Hay'at al-'āmma li-shu'ūn almațābi‘ al-amīriyya, 1959.

, al-Shifā. al-Manțiq III: al-'Ibārah. Edited by Maḥmūd Muḥammad Khuḍayrī. Cairo: al-Hay'at alMișriyya al-‘āmma li-l-ta’líf wa-l-nashr, 1970.

, al-Shifā. al-Manțiq V: al-Burhān. Edited by Abū al-'Alā 'Afīfī. Cairo: al-Mațba'at al-amīriyya, 1956.

, al-Ta'liquāt. Edited by Sayyid Ḥusayn Mūsaviyān. Tehran: Mū’assasah-i Pizhūhishī-i Hiikmat va Falsafah-i İrān, 2013.

Kāshif al-Ghițā, 'Alī. Naqd al-ārā' al-manțiqiyya wa-ḥall mushkilātihā. Beirut: Mū'assasat al-nu'mān, 1991.

Kātib Çelebi. Kashf al-z̧unūn. Edited by M. Şerefeddin Yaltkaya and Kilisli Rifat Bilge. Istanbul: Maarif Matbaası, 1941.

al-Kātibī, Najm al-Dīn. al-Shamsiyya fī qawāỉd al-manțiqiyya. Edited by Mahdī Faḍlallāh. Beirut: al-Markaz al-thaqāfī al-'arabī, 1998.

'Ayn al-qawā'id fi al-manțiq wa-l-hikma. Süleymaniye Library, MS Ragıp Paşa 1481.

Keynes, John N. Studies and Exercises in Formal Logic. New York: Macmillan, 1900.

al-Khūnajī, Afḍal al-Dīn Ibn Nāmāwar. Kashf al-asrār 'an ghawāmị al-afkār. Edited by Khaled el-Rouayheb. Tehran: Mū'assasah-i Pizhūhishī-i Hiikmat va Falsafah-i Īrān, 2010.

al-Madā'inī, Ibn Abī al-Ḥadīd. Sharh al-Āyāt al-bayyināt. Edited by Mukhtār Jablī. Beirut: Dār șādir, 1996.

Michot, Jean. “Avicenna's 'Letter on the Disappearance of the Vain Intelligible Forms after Death'." Bulletin de Philosophie Médiévale 27 (1985): 94-103.

Mīr Dāmād, Muhammad Bāqir. Kitāb al-qabasāt. Edited by Mahdī Muhaqqiq. Tehran: Intishārāt-i Dānishgāh-i Tehrān, 1988.

Mullā Șadrā. Metaphysical Penetrations / Kitāb al-Mashāirr: A Parallel English-Arabic Text. Translated by Seyyed Hossein Nasr, edited by İbrahim Kalın. Provo, UT: Brigham Young University Press, 2014.

Özpilavcı, Ferruh. Fârâbî’nin Önerme Anlayışı. İstanbul: Litera Yayınları, 2018.

Pehlivan, Necmettin. Klasik Mantıkta Ma'dûle Önermelerle Yapılan Çıkarımlar. Ankara: İlâhiyât Yayınları, 2016. al-Qūshjī, 'Alī. Sharḥ Tajrīd al-'aqā’id. Edited by Muḥammad Ḥusayn Zāri'î Rị̣ā'î. Qom: Rā’id, 2014.

al-Rāzī, Fakhr al-Dīn. al-Mabāhith al-mashriqiyya fì 'ilm al-ilāhiyyāt wa-l-tabī‘iyyāt. Edited by Muhammad alMu'tașim billāh Baghdādī. Beirut: Dār al-kitāb al-'arabī, 1990.

Manțiq al-Mulakhkhaṣ. Edited by Ahad Farāmarz Qarāmalikī and Ādīnah Aṣgharīnizhād. Tehran: Intishārāt-i Dānishgāh-i Imām Șādiq, 2002.

, Sharḥ al-Ishārāt wa-l-tanbīhāt. Edited by ‘Alī Riḍā Najafzādah. Tehran: Anjuman-i Ās̄ār va Mafākhir-i Farhangī, 1963.

Rescher, Nicholas. The Development of Arabic Logic. Pittsburgh: University of Pittsburgh Press, 1964.

al-Sāwī, 'Umar Ibn Sahlān. al-Bașā’ir al-nașīiyya fì 'ilm al-manțiq. Edited by Rafĩq al-'Ajam. Beirut: Dār al-fikr al-Lubnānī, 1993.

es-Semerkandî, Şemsüddin. Kıstâsu'l-Efkâr: Düşüncenin Kıstası. Edited and translated by Necmettin Pehlivan. İstanbul: Türkiye Yazma Eserler Kurumu Başkanlığı, 2014. 
Sorabji, Richard. The Philosophy of the Commentators, 200-600 AD. A Sourcebook III: Logic and Metaphysics. London: Bristol Classical Press, 2012.

al-Taftāzānī, Sa'd al-Dīn b. 'Umar. Sharh al-shamsiyya fi al-manțiq. Edited by Jād Allāh Bassām Ṣạliḥ. 'Ammān: Dār al-nūr al-mubīn, 2011.

al-Tahānawī, Muhammad A'lā b. 'Alī. Mawsü'at Kashshāf ișțilāhăât al-funūn wa-l-úlūm. Edited by 'Alī Farīd Daḥrūj. Beirut: Maktabat Lubnān, 1996.

[al-Taḥtānī], Quṭb al-Dīn al-Rāzī. "Sharḥ al-Ishārāt wa-l-tanbīhāt." In al-Ishärāt wa-l-tanbìhāt ma'a sharh alKhwāja Nașìr al-Dīn al-Ṭūsī wa-muhākamāt Quṭb al-Dīn al-Rãzī, edited by Karīm Fayḍī. Qom: Intishārāt-i Mațbūāât-i Dīnī, 2004.

, Sharḥ al-Mațālit. Edited by Usāma Sā'idī. Qom: Dhawī al-qurbā, 2016.

, Tahrìr al-qawāid al-manțiqiyya fi sharh al-Risālat al-shamsiyya. Edited by Muḥsin Bīdārfar. Qom: Intishārāt-i Bīdār, 2005.

Thom, Paul. "Al-Fārābī on Indefinite and Privative Names." Arabic Sciences and Philosophy 18 (2008): 193-209.

al-Ṭūsī, Nașīr al-Dīn. Asās al-iqtibās fĩ al-manțiq. Translated by Mullā Khusraw, edited by Hasan al-Shāfíì and Muhammad al-Sa'îd Jamāl al-Dīn. Cairo: al-Majlis al-a'lā li-l-thaqāfa, 2004.

, "Sharḥ al-Ishārāt wa-l-tanbīhāt." In al-Ishārāt wa-l-tanbīhāt, edited by Sulayman Dunyā. Cairo: Dār al-ma‘ārif, n.d.

"Ta'dìl al-mi'yār fī naqd Tanzìl al-afkār." In Collected Texts and Papers on Logic and Language, edited by Mahdī Muhaqqiq and Toshihiko Izutsu, 137-248. Tehran: Institute of Islamic Studies, McGill University Tehran Branch, 1974.

, Tajrīd al-'aqẫid. Edited by ‘Abbās Sulaymān. Cairo: Dār al-ma‘ārif al-jāmi'iyya, 1996.

Tajrīd al-manțiq. Beirut: Mữassasat al-a'lā li-l-mațbūāt, 1988.

'Ubūdiyyat, 'Abd al-Rasūl. al-Nizām al-falsafi li-madrasat al-hikmat al-muta'āliya. Edited by 'Alī 'Abbās Mūsawī and Khanjar Ḥamiyyah. Beirut: Markaz al-ḥaḍāra li-tanmiyat al-fikr al-islāmī, 2010.

Wolfson, Harry A. "Infinite and Privative Judgments in Aristotle, Averroes and Kant." Philosophy and Phenomenological Research 8, no. 2 (1947): 173-87. 